\title{
Challenges Associated with the Expansion of Deposit Insurance Coverage during Fall 2008
}

\author{
Sebastian Schich \\ OECD, Paris
}

\begin{abstract}
Government provision of a financial safety net for financial institutions has been a key element of the policy response to the current crisis, with governments extending existing guarantees and introducing new ones. These measures have been helpful in avoiding a further accelerated loss of confidence. But they are not costless. Like any guarantee, deposit insurance gives rise to moral hazard, especially if the coverage is unlimited. In the midst of a crisis, the immediate task is to restore confidence, and guarantees can be helpful in that respect. Nonetheless, to keep market discipline operational, it is important to specify when the extra insurance will end, and this timeline needs to be credible. To be able to establish such a timeline the root causes of the lack of confidence - that is the effects of troubled assets on financial firms' health-need to be addressed effectively. On a more fundamental level, once a government has ventured down the road of guarantee expansion, there may be a general perception that a government guarantee will always be available during crisis situations. As a consequence, other elements of the financial safety net may need to be strengthened, including the prudential and supervisory framework.
\end{abstract}

Published as Policy Paper

JEL: E61, G01, G22

Keywords: Policy responses to financial crisis; safety net; deposit insurance; moral hazard

Correspondence: Sebastian Schich, OECD, 2, rue André Pascal, 75775 Paris, France; e-mail: sebastian.schich@oecd.org

Sebastian Schich is Principal Economist in the Directorate for Financial and Enterprise Affairs of the OECD. The present article draws on material prepared by the author for discussion at the meeting of the OECD's Committee on Financial Markets and published in the OECD Financial Market Trends in December 2008. The present article does not, however, necessarily reflect the view of the OECD or any of its member countries. It has benefitted from comments from Francis Ahking, Achim Dübel, Stephen Lumpkin, Walker F. Todd, and the suggestions from an anonymous referee, although the author remains solely responsible for any errors. 


\section{Introduction}

Whenever a crisis hits, interest in guarantee arrangements rises. The current financial crisis is no exception in that respect. It puts the spotlight on the operation of the financial safety net and provides policy makers with a timely opportunity to monitor its performance, with a view to identifying its strengths and weaknesses. The present article focuses on one specific element of financial safety net elements - deposit.

While aspects of the design of deposit insurance schemes undergo rather infrequent and more or less gradual changes, the accelerated loss of confidence in financial markets in September and October 2008-as evidenced by several financial market indicators after the failure of Lehman Brothers Holdings - triggered a number of emergency policy actions linked to financial safety nets. There appears to be growing consensus that the overall effectiveness of these safety nets is largely a function of their weakest elements. Deposit insurance is one of several core elements of the financial safety net (second section) and a number of measures adopted in response to the financial turbulence were expressly intended to avoid having the deposit insurance function turn out to be that weakest element. The measures, described in more detail in the third section, included the following ones:

- In those jurisdictions of members of the OECD Committee on Financial Markets (CMF) where explicit deposit insurance arrangements had not existed, such schemes were introduced.

- In many of the jurisdictions where such arrangements were already in place, some design aspects were changed. Perhaps most notable among such changes were increases in the levels of maximum deposit insurance coverage, at least on a temporary basis, and in at least some instances withdrawals of co-insurance arrangements.

- Policy makers in some countries made statements that suggested (either explicitly or implicitly) that deposit insurance coverage would be unlimited. Coverage of guarantee arrangements was also extended in some cases to wholesale bank liabilities that have not traditionally been covered by such arrangements.

These and other related actions were aimed at restoring confidence among both financial intermediaries and the wider public. They tend to reduce the threat of bank failures by raising the likelihood that depositors and creditors continue to provide a stable source of funding for banks, while involving limited if any upfront fiscal costs (as compared to alternative policy choices such as capital injections and purchases of nonperforming assets). Thus, they buy time. There are nonetheless potential costs associated with these measures, which are discussed in the fourth section. Governmentprovided guarantees create contingent liabilities as well as other costs that arise as a result of potential distortions of incentives and competition. The fifth section argues that the extension of existing guarantees and introduction of new ones does not substitute for other measures that directly address the root causes of the lack of confidence. If 
anything, the expansion of guarantees up the ante on the need for the latter type of actions. The sixth section concludes.

\section{The Role of Safety Nets}

The current crisis is a forceful reminder that financial institutions and markets are susceptible to periodic problems of marked illiquidity and insolvency. These problems, if not addressed, can precipitate system-wide crises, which in turn can result in large economic and social costs. The costs can include losses on the part of depositors and investors, reduced access to credit on the part of individuals and firms, disruptions to payments and settlement systems, reductions in output and increases in fiscal burdens.

The current crisis is not the first significant financial crisis; in fact, during the past few decades there have been numerous such episodes worldwide in which financial sector problems have reached crisis proportions. Analysis by the OECD Committee on Financial Markets (CMF) has concluded that severe banking sector problems were indeed widespread among OECD countries during the 1980s and 1990s, sparked in many cases by apparent price 'bubbles' in real estate or equity markets, which had been supported in some cases or encouraged by favourable tax incentives and accommodative macroeconomic policies (Lumpkin 2002). These crisis episodes included among others the well-documented thrift crisis in the United States, banking failures in the Nordic countries, serious difficulties in France, Hong Kong, China, Italy, Japan, Spain, Mexico and Korea, as well as banking sector problems in Turkey and in the transition countries of Central and Eastern Europe.

Most episodes of financial instability have occurred after a change in the structural regime as a result of deregulation, liberalisation, or financial innovation, which altered incentives in unintended ways. Most crisis episodes featured significant accumulation of debt (in large part also mirroring the extension of credit as a result of competition to grow financial intermediation profits) and substantial accumulation of assets in an environment characterised by the cumulative effects of loose monetary policies over extended periods and very low risk premia, leading to a buildup of financial imbalances and growing leverage ratios in one or several segments of the economy.

The above described phenomena are recurrent, and this observation suggests that the financial system is characterised by an inherent tendency toward procyclicality. Periodically, there tends to be erosion in market discipline as participants compete for short-term profit opportunities, while neglecting due diligence. This lapse in discipline can take the form of declining underwriting standards on the part of financial institutions and/or the occurrence of herd behaviour of financial institutions and investors, ${ }^{1}$ typically involving a growing number of participants. The build-up of credit and asset price bubbles associated with these behavioural patterns feeds on itself until some shock triggers its collapse (Borio 2007). The shock itself by definition cannot be predicted and tends to vary from episode to episode. Brunnermeier (2009) provides an

\footnotetext{
1 A number of studies provide empirical estimates of the build-up of imbalances prior to and/or measures of the severity of crises (e.g. in terms of the effects on key economic variables), with recent examples including Keys et al. (2008), Laeven and Valencia (2008a), Mendoza and Terrones (2008), Reinhart and Rogoff (2009), and Tamirisa and Igan (2008). The author is grateful to the anonymous referee for having drawn his attention to several of these studies.
} 
explanation of the mechanisms that lead to problems arising in a rather small segment of financial markets (sub-prime residential mortgages) to spread quickly and widely to global financial markets in the current crisis episode.

A proper financial safety net is necessary to reduce the risk of severe financial crises. Without an appropriate financial safety net, even simple rumours of problems regarding solvency or liquidity of a financial institution, especially deposit-taking ones, have the potential to become self-fullfilling and turn into a full-blown crisis. With an appropriate financial safety net in place, confidence tends to be greater, the onset of financial crises is less likely than otherwise, as is the likelihood that an episode of financial stress evolves into a severe financial crisis.

A financial safety net consists of (at least) three key elements, the lender of last resort, deposit insurance, and the prudential and supervisory framework, while a wider definition also includes a dedicated failure resolution mechanism for financial institutions. The present note focuses on aspects of the deposit insurance component of the financial safety net (Figure 1).

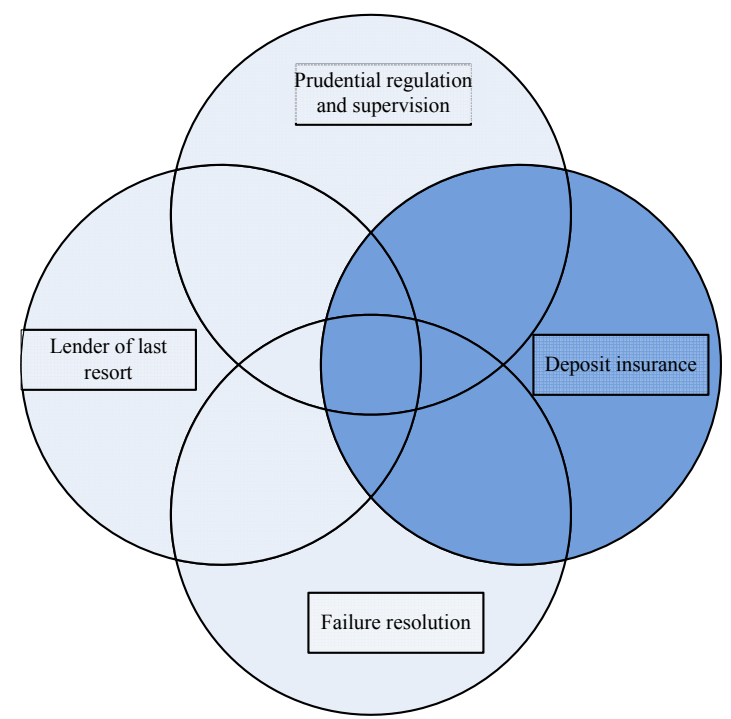

Figure 1. Interrelations between Elements of Financial Safety Nets (Schich 2008b)

Each of the different elements faces a similar trade-off. On the one hand, these elements are designed to reduce the disruptions in the financial system stemming from the failure of financial institutions. On the other hand, they have to be designed in a way that they reduce ex ante moral hazard risk that otherwise can result in the same fragility that the financial safety net is supposed to minimise. Flaws in the design of safety nets can even encourage institutions to make themselves vulnerable to the particular shock that could trigger a crisis (Demirgüç-Kunt and Detragiache 2002). An efficient prudential and supervisory framework can limit moral hazard risk. 


\section{Changes to Deposit Insurance Arrangements as Part of Emergency Measures Implemented in Fall 2008}

\subsection{Emergency Policy Measures Taken in Fall 2008}

In the fall 2008, following the bankruptcy of Lehman Brothers Holdings, confidence among banks fell further. At the same time, it became increasingly clear that the policy interventions to date had not been successful in restoring confidence in markets and among the wider public. There was a growing sense that the financial turbulence could develop into the worst financial crisis since the Great Depression. The nervousness and distrust spread from the banking sector to the wider public. Among other things, bank customers in several jurisdictions were reportedly shifting from deposits to the perceived safety of other institutions or instruments. At the same time, it became increasingly clear that the case-by-case approach adopted by many governments did not have the desired effect.

Against this background, a great number of emergency policy measures were implemented, several of which related to deposit insurance arrangements. Government responses to the crisis changed from the earlier case-by-case approach to a more systematic approach, whereby the lack of confidence and frozen credit markets were tackled by two sets of measures. One set of measures aimed at ensuring banks' continued access to funding through the provision of guarantees (either retail or wholesale). The other set of measures aimed at addressing banks' undercapitalization by injecting capital or purchasing specific assets. Figure 2 visualises these sets of measures, which allows one to place the measures related to retail deposit insurance in the context of other bank rescue measures that were announced in fall 2008, using the example of G-7 countries. At the same time, central banks, in their roles as 'lenders of last resort' continued to be a source of liquidity support to financial institutions, most often in the form of loans extended against collateral (the range of which became considerably wider in many cases), with the size of these entities' balance sheets increasing significantly. ${ }^{2}$

Like any safety net, the strength of the financial safety net is determined by the strength of its weakest element. In this context, it is helpful to remember that a report by the FSF Working Group on Deposit Insurance from September 2001 concluded that, at the level of each country, a well-established mechanism needs to exist in all key areas constituting the financial safety net. The report stressed that if a country has established a well-developed mechanism in only some but not all of these areas, it is still likely to face difficulties in finding effective solutions for preventing or resolving serious problems in its banking system.

\footnotetext{
2 Extensive use of the lender of last resort function (LOLR) has indeed been another key element of the provision of the financial safety net by public authorities. Like any element of the financial safety net, the LOLR function has to strike the right balance between achieving stability and generating moral hazard. Also, additional issues may arise from the interactions of the LOLR and the deposit insurance functions. Conceptually, the allocation of responsibilities between these two function is straightforward, as long as illiquidity and insolvency can be clearly separated. In practice, however, this situation is often not a realistic suggestion and tensions between the two functions may arise. For example, if the LOLR intervened to lend against good collateral to an institution that might eventually become insolvent, the central bank would effectively reduce the collateral available for depositors and other creditors.
} 


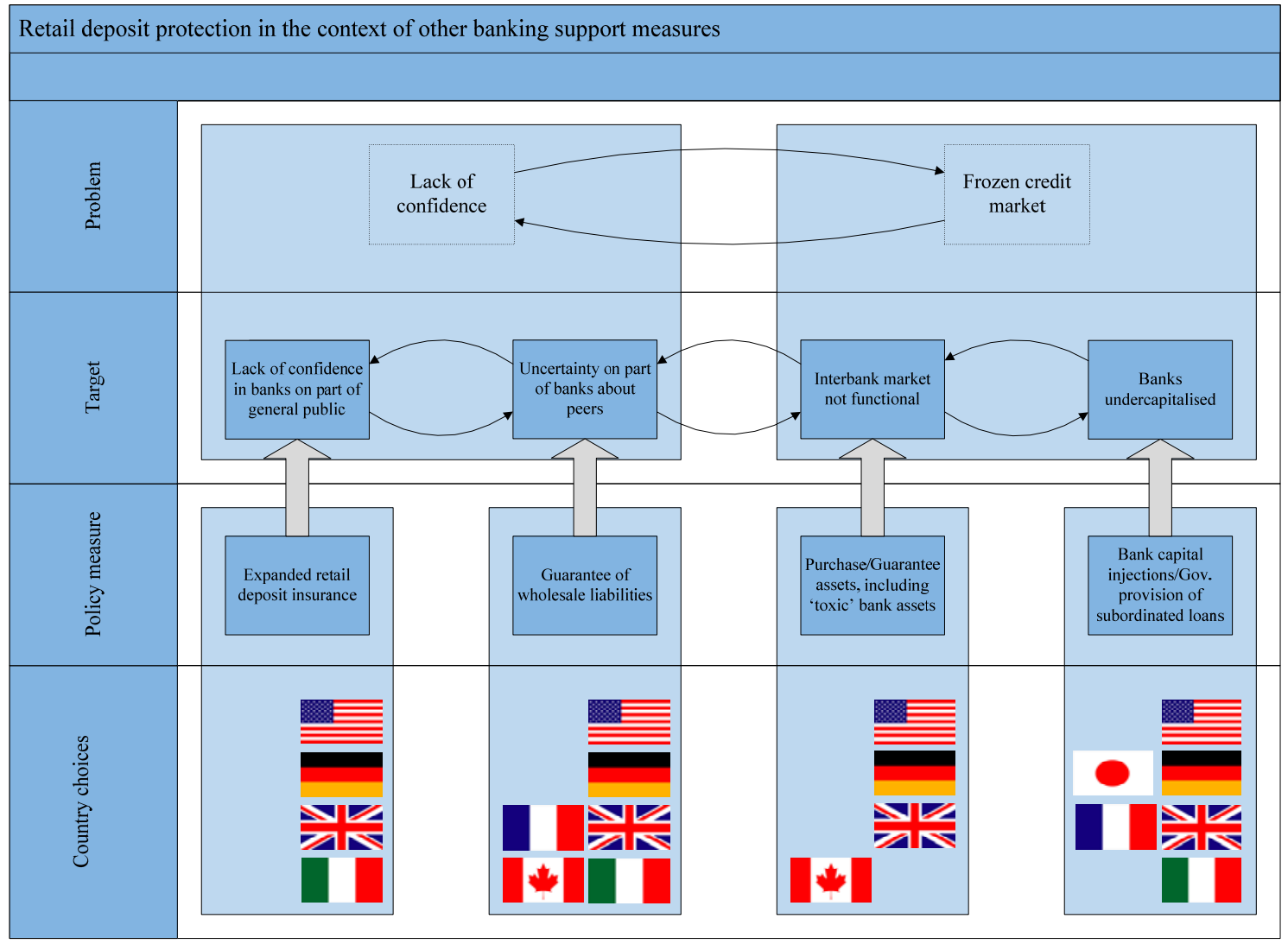

Figure 2. Expansion of retail deposit insurance in the context of other bank rescue measures announced and/or implemented in G-7 countries (Update from Schich (2008b)).

Note: The Figure shows measures implemented or announced (or those for which capacity for implementation has been created). For example, the Japanese government has not yet had to inject capital into banks during the current financial crisis, although related facilities exist and/or are being reintroduced. In Canada, the Canadian Lenders Assurance Facility (CLAF) announced that it will make available government insurance of up to three years, on commercial terms, for borrowings by banks and other qualifying deposit-taking institutions. The government will also purchase pools of insured residential mortgages. In Italy, legislation created the capacity for the Ministry of the Economy to expand the (already high) level of deposit protection, to guarantee wholesale bank liabilities and to inject capital into banks, but it has not had to implement any of these measures. In the United Kingdom, in January 2009, the Government announced a range of further measures and schemes to support the banking sector, including this time a new asset protection scheme under which the state will provide credit risk insurance to banks and building societies for certain assets. For the remaining countries shown here, the information relies on the OECD Economic Outlook 84. Estimates as of January 2009.

According to many observers, the episode involving Northern Rock in the United Kingdom testified to the importance of that advice. The deposit insurance mechanism turned out to be a weak element in the country's financial safety net. In particular, because of the inadequacy of the deposit insurance system, the situation at Northern Rock triggered fear of contagion with systemic implications. In addition, it has also been argued that the country's reliance upon general bankruptcy laws hamstrings the supervisors' ability to intervene and leads to delays in resolving banking failures when they occur, thus weakening the effectiveness of deposit insurance arrangements. Be that as it may, many of the issues related to deposit insurance that were highlighted by this episode were not specific to the United Kingdom. They were relevant for the systems in 
place or under study in other countries as well. This suggestion has been underscored by the large number of policy measures taken in the fall 2008, which included raising the maximum levels of coverage and extending coverage to a wider range of deposits.

\subsection{Raising the Maximum Levels of Coverage}

A consensus among policy makers seems to have been emerging that one of the lessons from the run on mortgage lender Northern Rock in the United Kingdom is that deposit insurance systems with low levels of coverage and partial insurance, together with likely delays in repayment, may not be effective in preventing bank runs" (Schich 2008a). The policy actions taken in the fall 2008 reflected this understanding (although at least some of the changes may have gone beyond levels that, at that time, might have been considered adequate).

For example, in the United States, the maximum amount of insurance coverage provided per depositor per bank was raised (initially on a temporary basis) from USD 100,000 to USD 250,000 in early October. In Europe, finance ministers agreed on raising the level of deposit guarantee protection to EUR 50,000 at the beginning of October, while some European governments went beyond that limit and raised coverage levels in their jurisdictions to EUR 100,000. In mid-October, the European Commission announced its plans to require EU member countries to increase their deposit guarantee within a year to at least the latter amount. On 8 December, the European Parliament's Economic and Monetary Affairs Committee agreed on raising the deposit guarantee level to EUR 50,000, rather than the present EUR 20,000, from 30 June 2009 and harmonising the level at EUR 100,000 from 31 December 2011.

A remarkable feature of the changes announced in the fall 2008 was the introduction of unlimited retail deposit coverage in some jurisdictions. Announcements to that effect were either made explicitly or implicitly, in the form of statements by policymakers suggesting that all retail deposits were covered by a government guarantee, without necessarily involving statutory changes.

The implications of the changes in the deposit insurance ceilings announced or suggested by policy statements are shown in Figure 3, using the example of OECD countries (and including as well observers to the meetings of the OECD Committee on Financial Markets). It shows the USD equivalent of the maximum deposit insurance coverage as of December, compared to the situation in mid-September 2008 (using bilateral exchange rates as of early December in the case of both dates to eliminate changes induced by exchange rate movements). Where policy statements suggested or were interpreted as suggesting unlimited deposit insurance coverage, the figure contains a value of USD 1 million (which is being chosen for presentational purposes only). One observation is that many, but not all of these countries changed their deposit insurance ceilings and that all changes are upwards adjustments of coverage ceilings. There were no changes in just eight jurisdictions, while changes have taken place in 25 out of the 33 jurisdictions covered here. In nine of them, unlimited deposit insurance coverage was introduced.

Another way to look at the data on changes that have taken place is provided in Figure 4. The figure shows the incidence of specific deposit insurance coverage limits, comparing the situations in early December 2008 with that in April of the same year, 


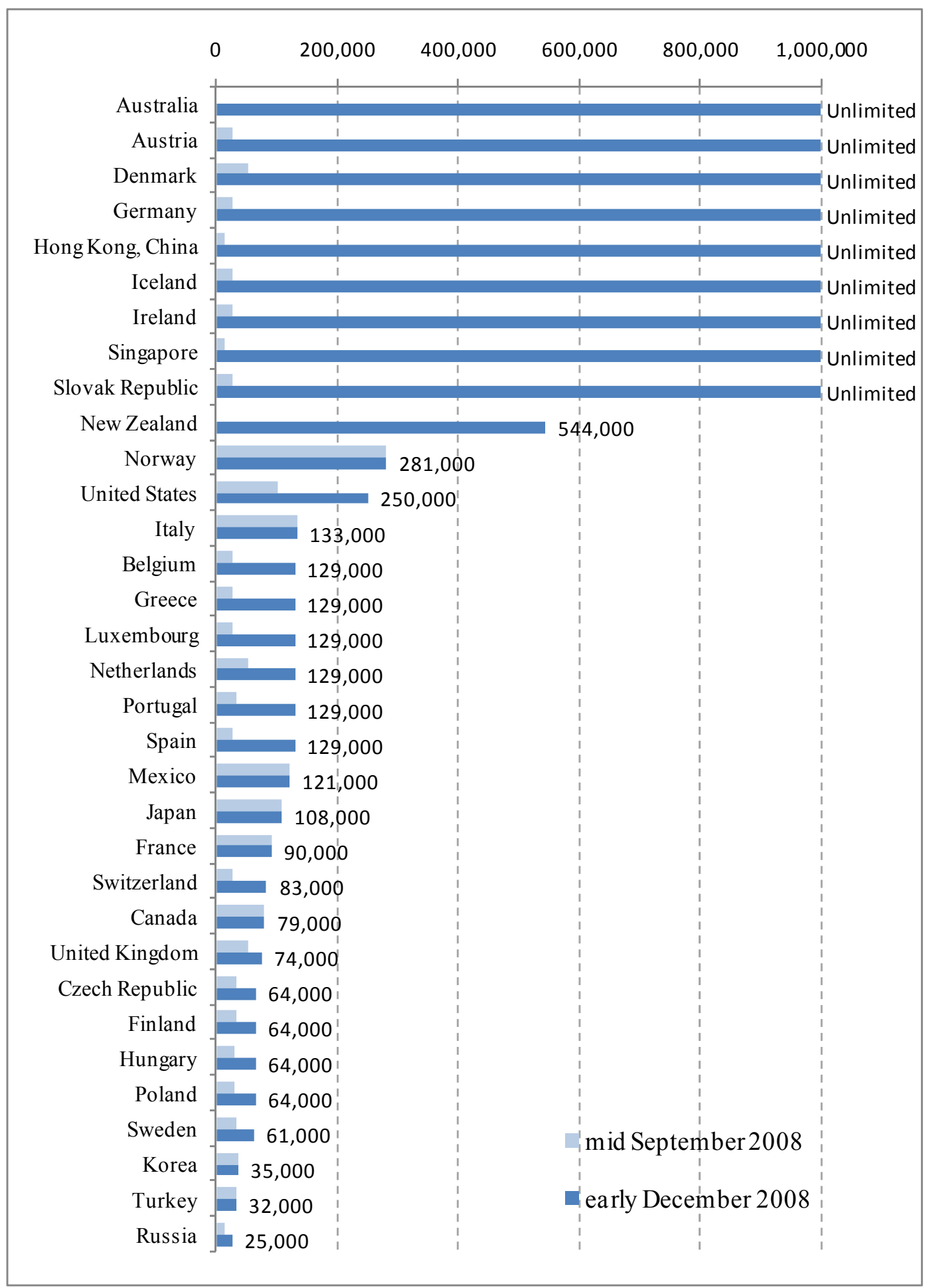

Figure 3. Deposit Insurance Coverage Limits (Schich 2008b)

USD equivalents, at current exchange rates, as of mid-September and early December 2008

using current exchange rates to convert local currencies into USD equivalents. The figure shows that the mass of the distribution has now noticeably shifted rightwards since April (while the recent strengthening of the US dollar exchange rate would tend to shift the more recent observations to the left). As a result of these changes, one might 
expect there to have been some convergence, among the different jurisdictions represented, towards a specific higher level of maximum deposit insurance coverage.

As it turns, whether such convergence has indeed taken place is not so clear. For example, Figure 4 illustrates that, according to one specific measure of the distribution of deposit insurance ceilings, there may not have been much convergence. In April 2008, a majority of jurisdictions specified ceilings that ranged between the equivalent of USD 25,000 to 50,000. By contrast, in early December 2008, there was no such (single) range that contained the majority of jurisdictions. Clearly, observations based on this simple measure should not be used to draw any firm conclusions, as the measure is highly sensitive to the choice of ranges and movements in exchange rates. In any case, looking forward, further convergence might be expected, especially among European jurisdictions. $^{3}$

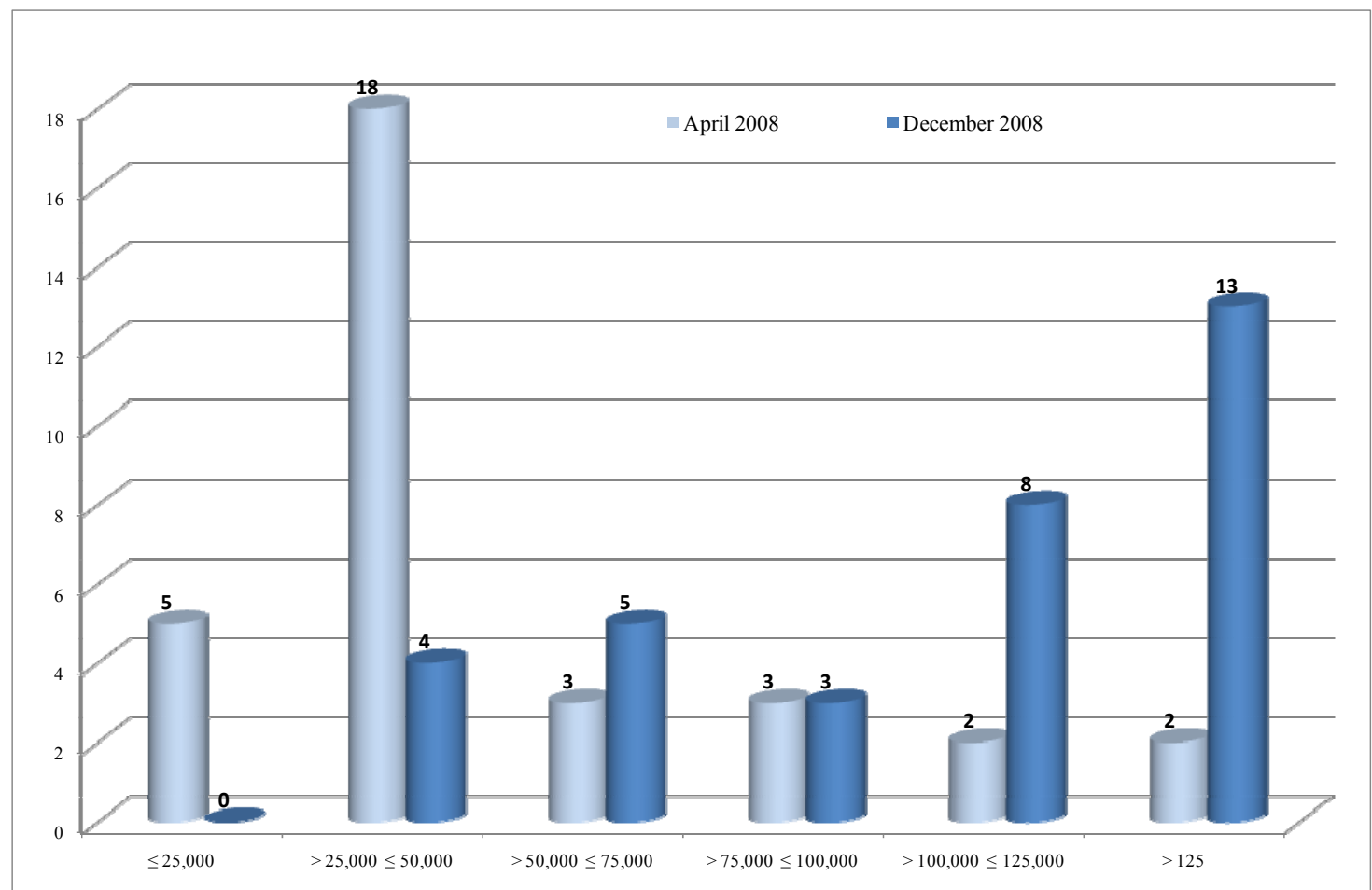

Figure 4. Incidence of Specific Deposit Insurance Coverage Limits (Schich 2008b)

Numbers of constituencies, ranges in USD equivalents converted at current exchange rates, as of end-April and early December 2008

\subsection{Extending Coverage to a Wider Range of Deposits}

As part of a broader strategy to restore public confidence (see Figure 2 for selected countries and measures), some governments have extended guarantees to unlimited coverage of retail deposits and of corporate deposits, as well as to other forms of unsecured bank debt. For example, in mid-October, the FDIC extended the coverage of

3 In this context, a Report on Deposit Guarantee Schemes by the European Commission is scheduled for end 2009. 
its scheme to small business deposits. Already at the end-of-September, the Irish government had guaranteed all deposits held in its six largest banks.

Finally, where explicit deposit insurance schemes had not existed, depositor protection was raised through the introduction of such schemes. Australia, which had established an early access facility in June 2008, extended in October 2008 a three-year guarantee on all deposits in the country's banks, building societies and credit unions, which was subsequently slightly modified. Under these new arrangements, all deposits at Australian authorised deposit-taking institutions are automatically guaranteed up to 1 million Australian dollars and larger deposits can be guaranteed on payment of a fee, which is the same that applies to the government guarantee covering wholesale funding. At the same time, the finance minister of New Zealand announced that the government had introduced an opt-in deposit guarantee scheme, with fees charged as a function of the growth in liabilities since mid-October 2008.

One important observation is that, overall, policy actions taken did not always appear to be closely co-ordinated across borders. Even though there was a widely shared sense that there was a strong need for communication and coordination of emergency policy actions, the actual implementation of measures, their timing, and sometimes also the statements accompanying the announcements themselves suggest that coordination was not as close as one might have hoped. Despite several efforts, including on the part of the European Commission, this observation also applies to the European Union. Perhaps notable exceptions were the responses by Australia and New Zealand, the announcements of which were co-ordinated, even though the respective measures taken differed.

\section{$4 \quad$ Challenges Raised by Recent Policy Measures}

The measures taken were helpful in preventing a further deterioration of confidence among depositors and perhaps also banks. This said, in some instances it may not have been clear how the (explicit or implicit) unlimited coverage would relate to the deposit insurance arrangements that were already in place. As a result, such announcements, being ad hoc in some cases, were perhaps not successful in restoring confidence to the full extent intended. There are nonetheless potential costs and challenges associated with these measures. Some of the challenges raised by the expansion of existing guarantees or the introduction of new ones are discussed in the remainder of this section.

\subsection{Moral Hazard}

Perhaps foremost among the challenges is that, like any guarantee, deposit insurance coverage gives rise to moral hazard. Deposit insurance can give rise to moral hazard both on the part of depositors, who may reduce their monitoring and "policing" efforts, as well as on the part of banks, which may perceive the lessening of the threat of market discipline. Depositors, especially large and perhaps sophisticated retail and wholesale depositors can impose market discipline, as they have the option to shift deposits from one bank to another if they deem one bank more likely to fail than another. 
With most deposit insurance schemes, the response to this trade-off historically has been to establish coverage limits that gravitate towards covering the vast majority of small depositor's balances while ensuring that large, especially corporate and interbank, deposits are exposed to market discipline. Despite this similarity in the approach, there typically has been no agreement on a specific value of maximum coverage across different jurisdictions. More recently, abstracting from the special case of explicit or implicit unlimited coverage, there may have been some convergence with respect to the maximum coverage level per person and per bank. At the same time, more divergence may have been introduced by the fact that coverage of deposits in some jurisdictions has been extended beyond those of retail deposits to other types of deposits (as well as other types of liabilities).

Arguably, moral hazard is most relevant in the case of (either implicit or explicit) provision of unlimited deposit insurance coverage. This assessment partly explains why unlimited deposit insurance coverage has rarely been given. Some countries have provided such unlimited coverage in the initial response to a banking crisis, but they have typically attempted to withdraw full coverage once the crisis seemed to abate.

Perhaps as important as the crisis itself is the policy response to it in influencing the functioning of financial markets in the future. Even in the midst of a financial crisis officials should not lose sight of the policy goal of supporting efficiently operating financial markets. The manner in which policy makers manage and resolve the current crisis will affect market particpants' expectations regarding future policies and, perhaps, the likelihood and depth of future crises, through the impact it is likely to have on market discipline (Demirgüc-Kunt and Servén 2009). For example, providing guarantees for extensive periods including to insolvent institutions subsisdizes "gambling-for-redemption" strategies, thus undermining market discipline. The latter should be allowed to operate, however, as it can help reduce the final costs of settling a banking crisis. Indeed, the historical evidence suggests that different exit strategies can result in considerably different costs for the deposit insurer, government, and the public at large (Lumpkin 2008; Laeven and Valencia 2008b).

Moreover, market discipline can play a significant role, in particular, in situations when the performance of regulatory and supervisory frameworks and authorities is not as smooth as had been intended. Indeed, in the view of many observers, such an assessment describes the performance of these frameworks during the recent turmoil. Strengthening regulatory and supervisory frameworks is one possibility of addressing moral hazard, but the need to rely on that framework is arguably lessened if market discipline is allowed to play a role.

To allow for a greater role for market discipline and limit moral hazard it is important to specify when the extra deposit insurance will end (as some governments have done), and this timeline needs to be credible. Absent a credible "exit strategy", government guarantees once implemented can be difficult to withdraw. The difficulty, during the midst of a crisis, with specifying specific timetables for the phasing-out of extended guarantees is, however, that there is considerable uncertainty about the duration of the crisis. 


\subsection{Funding Issues}

Sound funding arrangements are critical to the effectiveness and credibility of the deposit insurance system. Explicit deposit insurance systems can be either funded or unfunded or consist of a combination of both elements. Many schemes in CMF member jurisdictions have ex ante funding elements and in many cases differential premiums are levied, some of which are risk-adjusted. While use of risk-based premiums tends to reduce the moral hazard problem associated with the provision of deposit insurance, it has proved difficult in practice to determine the correct levels of such premiums. Where guarantees are expanded from deposits to include senior and subordinated debt liabilities for temporary periods of time, the issue of funding is particularly relevant given the potential for moral hazard. Such guarantees should include some risk-related cost to the institutions that receive coverage, but determining risk-adjusted premia is very difficult in practice, especially as relevant experience is scarce.

Ex ante funding involving a stand-alone deposit insurance fund ensures that funds will be available for depositor compensation when needed, provided premiums charged reflect appropriate assumptions regarding potential losses and other deposit insurance costs. Under such circumstances, the provision of timely access by depositors to their insured deposits is facilitated, as no additional government action or decision is required.

In this context, it is important to maintain an appropriate ratio between the size of the fund and the amount of total insured deposits; the "adequacy" of such a ratio depends on the goals of the deposit insurance system, that is, on the specific mix of consumer protection and financial stability objectives and the outlook for the latter. The information publicly available from deposit insurance agencies suggests that most of them do not have a specific quantitative target for the reserves in the fund as a function of the insured deposits. In the cases where the existence of such targets could be verified using publicly available information, their values range from a few decimal points of a per cent up to 10 per cent of total deposits.

In the case of deposit insurance systems with ex ante funding elements, funding levels can turn out to be inadequate once bank failures accumulate (while reducing the likelihood of this situation arising can also be very costly, as funds collected ex ante would need to be invested in liquid securities with potentially lower returns). In these situations, similar to the case of ex post funding, the difficult issue arises as to how funds should be collected after bank failures. This issue can be complicated by a difficult market situation in the wake of the bank failure(s), especially if the failure(s) was (were) not an idiosyncratic event. In such situations, efforts to raise additional funds would run the risk of reinforcing (downward) cyclical developments.

For example, in the United States, the failure of several depositary banks including a large one during 2008 underscored the relevance of these funding considerations. As a result of the losses resulting from these failures, the FDIC's reserve fund was reduced significantly, although it should be noted that there is uncertainty about the ultimate losses associated with these interventions (i.e. much of that cost could be recovered in the future as the FDIC liquidates the assets held by those institutions). The FDIC is required to maintain a specific minimum level of the fund in relation to the total amount of insured deposits: When the fund balance divided by the level of insured deposits slips below 1.15 percent or is forecast to fall below that level within six months, the Deposit Insurance Reform Act of 2005 directs the agency to take steps to reach the 1.15 percent 
ratio within five years. At the beginning of 2007, when the Deposit Insurance Reform Act of 2005 came into effect, the FDIC charged fees in that year for the first time after about a decade. Indeed, over the decade from 1996 to 2006, the FDIC had waived premiums that it normally would have collected to insure bank deposits. In the fall of 2008 , the reserve ratio fell to close to 1 per cent and the agency proposed a significant increase in the fees it charges banks, on average. It expects that its reserve funds' balance may fall further before it eventually stabilises as a result of the higher premium income flow. This experience highlights the difficulties in maintaining adequate funding levels even in situations where important ex ante funding elements are present. In any case, recent legislation increased the agency's authority to borrow from the United States Department of The Treasury to meet deposit insurance system funding needs.

To make a guarantee credible it is important to specify the manner in which it will be provided. Some deposit insurance funds are given an explicit borrowing line from the government among other means of emergency funding. The capacity of governments to provide for the implicit or explicit guarantees that they have announced may be questioned, however, especially when the guarantees suggest no limits to total coverage. In such a situation, the fiscal contingency created can be very large. In this context, it has been pointed out that some countries have financial institutions that are large in terms of deposits and assets compared to their own gross domestic product. In the case of some smaller countries, indeed, the aggregate amount of deposits of customers at the largest banks could exceed the country's gross domestic product by quite a large margin (Figure 5).

The relevance of the issue of a country's fiscal capacity has been underscored by the experience of Iceland, where the government saw its set of policy options effectively limited as the size of the largest banks' balance sheets was large compared to that of the government. The Icelandic deposit insurance fund was funded to the tune of EUR 100 million, while deposits at Icelandic branches in Germany alone amounted to more than EUR 300 million. There were also large branches of Icelandic banks in the United Kingdom and the Netherlands. Inasmuch as the home country retains responsibility for insuring deposits in its banks' foreign branches, issues related to the compensation of depositors of branches of Icelandic banks in these three countries complicated negotiations related to international help for the country. A stand-by arrangement with the International Monetary Fund was concluded as well as bilateral arrangements between Iceland and the three countries, as a result of which funding was made available to compensate depositors up to the limit specified under (previous) EU rules (that is up to a maximum of EUR 20,000 per depositor). In such situations, international co-ordinated efforts may be necessary to allow for successful bank rescue operations. Clear frameworks for such operations do not exist, however. In this context, the recent Icelandic crisis has illustrated that additional costs can arise when there are no such frameworks and when international policy actions need to be decided during a crisis situation in a largely ad hoc fashion. By contrast, the mere existence of international policy arrangements set up in advance, perhaps in the form of mutual insurance arrangements or pre-arranged borrowing lines among schemes on specific terms, may prevent a crisis of confidence from occurring. 


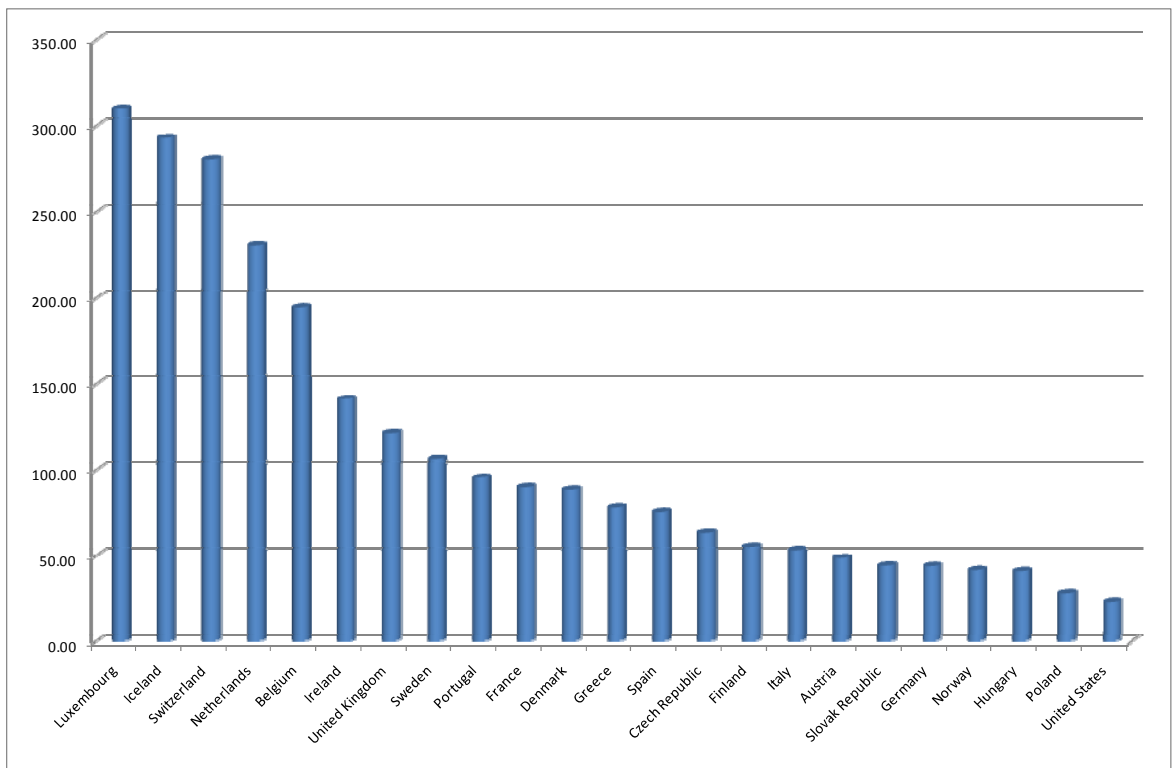

Figure 5. Relative Size of Deposits at Large Banks in Sselected OECD Countries (Author's estimates based on Lannoo (2008) and OECD (2007))

Aggregate amount of deposits from customers at the top 5 banks, expressed as a ratio of country's GDP as of 2007

\subsection{Issues Raised by the Coexistence of Different Levels of Protection}

Some policy statements announcing the introduction of new guarantees or increases in coverage levels under existing ones have made explicit references to the actions taken in other countries. For example, in the case of some of the announcements introducing blanket guarantees, such actions were justified as efforts to undo competitive disadvantages arising from the introduction of similar guarantees elsewhere. More generally, there is indeed a perception that the provision of guarantees might provide some financial institutions or sectors with unfair competitive advantages as compared to their peers that operate in the same or similar market segments but with more limited, if any, deposit insurance guarantees. The unfair advantage could be vis-à-vis other forms of savings (e.g. close substitutes to bank deposits) or vis-à-vis other deposit-taking institutions that do not enjoy the guarantee. The latter institutions could be located in the same country or elsewhere.

In this context, the Irish governments' guarantee to six large Irish banks led to inflows of funds into Irish bank offices in the United Kingdom, as deposits with these entities were covered by these guarantees. Such deposit flows are arguably more likely the more limited are transaction costs and exchange rate risks, an example being the euro area countries, which share a common currency. Against this background, the European Commission has continuingly stressed the need for co-ordinated policy actions, including in the area of deposit insurance arrangements, in the context of efforts related to its "Financial Stability Roadmap". More recently, a press release by the Council of the European Union (Brussels, 2 December 2008), backing efforts towards harmonisation of deposit insurance ceilings, stated that "harmonisation should make it possible to avoid the distortion of competition among banks which appeared during the financial crisis (in the form of massive deposit transfers from banks affiliated to a 
scheme offering a low coverage level to banks affiliated to a scheme offering a high coverage level."

It would appear that the possibility of massive shifts of deposits as a result of differences in the generosity of deposit insurance systems across countries is more limited where currencies differ from one country to another, thus giving rise to currency risk in the case of cross-border deposits (in the currency of the home country). Also, there may be transaction costs, especially in the case of automated teller machines and credit card transactions, and potential tax implications, that would make such moves unlikely in the case of most ordinary savers.

Perhaps more relevant is the possibility of significant shifts of deposits by sophisticated and wealthy retail and corporate depositors, as well as other banks or other financial institutions. One would expect that these depositors are capable of shifting their deposits quickly in response to differences in the extent of guarantee provided or in response to small differences in interest rates in situations where unlimited coverage is provided in either case. The expansion of guarantees or introduction of new ones has sometimes involved providing insurance coverage for depositors other than ordinary retail depositors. Also, other types of debt have also been guaranteed, and these guarantees may have had a bearing on the decisions of investors buying bank debt.

Conceptually, the value of an unlimited deposit guarantee is greater, the more reliant banks are on deposits and the more they are exposed to the risk that these deposits might be withdrawn. In particular, the higher the loan-to-deposit ratio, the more valuable should be guarantees of retail (and wholesale) liabilities. Deposits are typically a key source of the funding of banks, although this percentage differs considerably across banks and banking sectors. Figure 6 shows deposits (including both retail and wholesale, but excluding interbank deposits) as a percentage of total liabilities for selected banking sectors in the OECD. On aggregate, (customer) deposits are relatively high in some countries, such as the United States and Canada, and much lower in other jurisdictions, such as in France and Italy. Having said that, such measures are crude and they hide the considerable differences that exist between individual institutions in each sector.

In any case, it is notoriously difficult to price guarantees of either retail deposits or wholesale liabilities; hence, there is a risk that guarantees are mispriced even where governments undertake substantial efforts to levy risk-based charges.

On a different issue, within a country, the coexistence of different levels of deposit insurance for host country banks and branches of foreign banks can give rise to consumer protection issues. For example, under current EU rules, depositors of a bank's foreign branch (rather than subsidiary) are protected under the laws of the home country of the bank. Thus, to the extent that the host country of a bank is a member of the European Economic Area (EEA) and has implemented EU Directive 94/19/EC on Deposit Guarantee Schemes, under current rules a minimum deposit protection of 20,000 EUR in the bank's branches operating in other Member States of the EU/EEA would also be provided (although the European Parliament has recently adopted new rules that foresee that this amount will rise temporarily to EUR 50,000 as from July 2009 and subsequently to 100,000 as of end-2010). But whether these branches join a supplementary scheme in host countries that have a guarantee above the EU minimum level is another issue. There is a possibility that they do not participate in such supplementary schemes and that depositors are not fully aware of such choices; rather, 


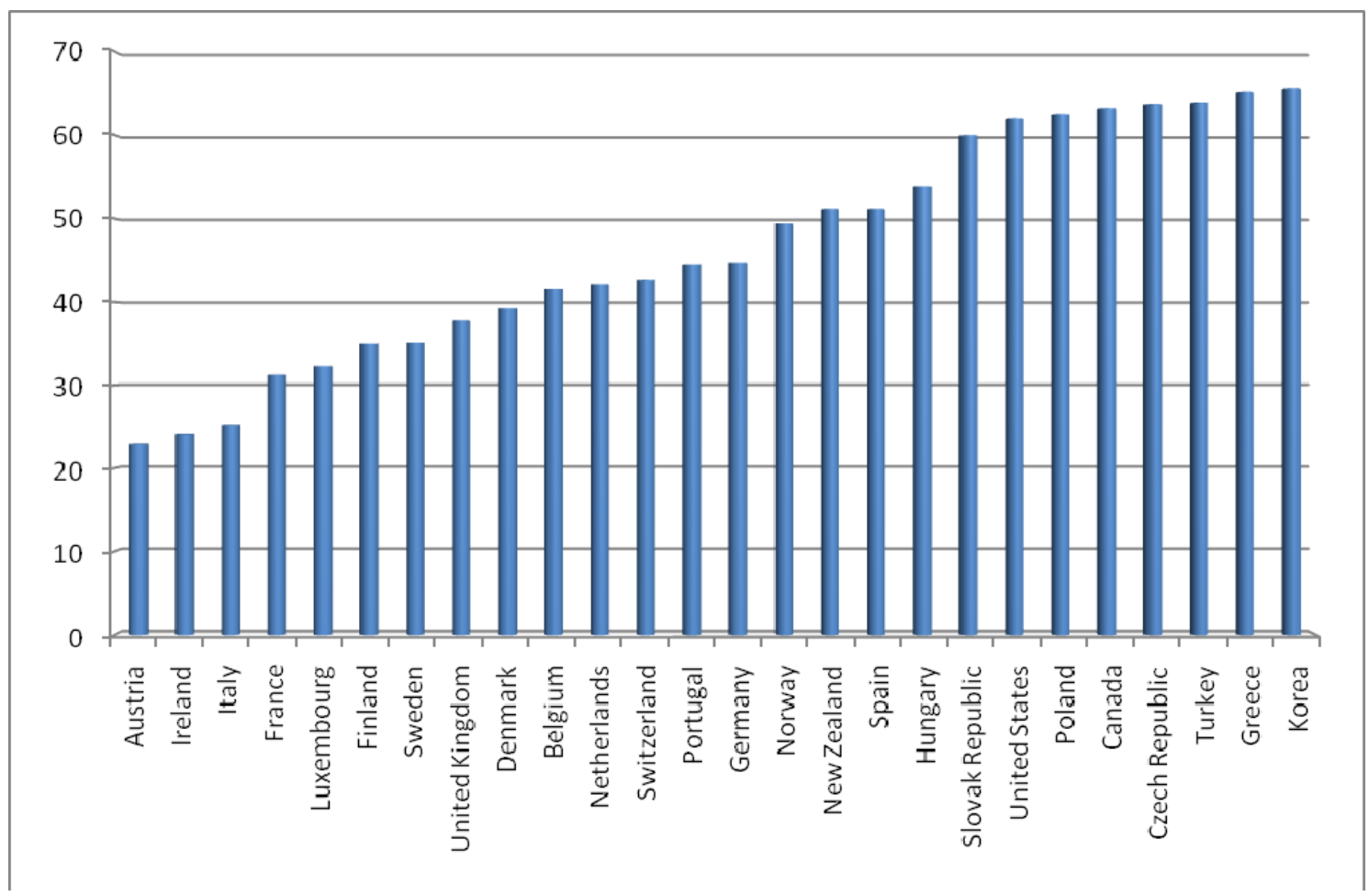

Figure 6. Customer Deposits as a Share of Total Bank Liabilities in Selected OECD Countries (Authors estimates based on Lannoo (2008) and OECD (2007))

Note: Customer deposits as a percentage of aggregate liabilities of banking sectors ("all banks") for all countries except Greece, Portugal, and Turkey ("commercial banks" only) and the United Kingdom ("large commercial banks" only), as of 2005.

they may expect that these branches are covered by the supplementary schemes that exist in host countries. The relevance of this issue has been underscored by the experience in several EU countries with branches of at least one Icelandic bank.

Also, to the extent that other forms of deposits or bank liabilities do not enjoy a guarantee, an unfair advantage for the deposits enjoying such a guarantee might arise or be perceived to exist, as a result of which there could be massive shifts of funds. To reduce the possibility of such shifts (and, more generally, as a means to restore confidence in banks) and the potential adverse implications associated with them, one approach has been to widen the guarantees to other forms of deposits or bank liabilities. In those situations, the difficult issue arises as to where to draw the line. The same issue of where to draw the line has arisen with respect to other forms of investments that have characteristics that are close to those of bank deposits but are offered by different types of financial service providers. The relevance in practice of this issue was underscored by the experience in Australia, where the introduction of explicit deposit insurance (in an attempt to ensure a level-playing field for domestic banks compared to their international competitors) was followed by several adjustments of the scope and fee structure of that arrangement, required to ensure a level playing field among different financial service providers. As part of that process, the government even extended the guarantee to deposits in branches of foreign banks. 


\section{$5 \quad$ Addressing the Roots Causes of Confidence Problems Becomes Even More Cruical}

A guarantee reduces the threat of bank failures by raising the likelihood that depositors, which provide a large part of funding for banks (Figure 6), continue to provide a stable source of such funds. The expansion of guarantees or the introduction of new ones thus buys time, as it increases the chances that existing deposits will not be withdrawn. Clearly, a full guarantee of bank deposits can be particularly helpful in that respect.

Having said that, while guarantees buy time, this time needs to be effectively used to solve the fundamental problems facing banks. Indeed, as regards the extension of unlimited retail deposit coverage, it is recognized that such measures, once implemented, should be withdrawn as rapid as a country's circumstances permit (Financial Stability Forum 2001), al-though only at the point when the financial system is again sufficiently resilient. Otherwise, additional costs could arise. As another FSF document put it: "After a country has suffered a financial crisis, it is best to ensure that most of the major problems relating to the financial crisis have been adequately addressed before transitioning to limited-coverage deposit insurance. However, if governments wait for all deficiencies in an economy or financial system to be address or the system to be reformed, blanket guarantees could become entrenched" (FSF Working Group on Deposit Insurance 2000: 12).

The experience of Japan illustrates the difficulties in withdrawing extended guarantees. In that country, initial policy responses to the banking crisis in the early 1990s was forbearance, provision of emergency liquidity, assistance to encourage mergers of failed institutions, and strengthening of deposit protection (Nanto 2008), while monetary and fiscal policy measures were limited. The failure of measures to rescue the banking system and address the root causes of the problem of nonperforming loans led to a substantial swing in sentiment from excessive risk appetite to extreme risk aversion. It took an extraordinary long time for the recovery of the banking sector to take place and this observation can be explained also by the stringent conditions applied for the assistance provided in the earlier support packages. Since banks were unwilling to accept the conditions, they side-stepped government support and tried to bolster their balance sheets by cuts in lending. As a result, Japan suffered an extended period of negative or weakly positive growth, which in turn complicated recapitalisation of the Japanese banking sector.

After Japanese banks started to suffer from the nonperforming loans crisis in the 1990s, the Deposit Insurance Act was revised in 1996 to temporarily lift the deposit insurance coverage limit of Yen 10 million (about USD 95,000) per person per bank, so as to insure all deposits without limit. The original limit was intended to be reinstated in April 2001, but its reinsertion was then postponed to April 2002, and even then it was only gradually lifted; first for time deposits on that date, and subsequently for ordinary deposits (except deposits that bear no interest, are redeemable on demand, and provide payment and settlement services; see also Figure 7). 


\begin{tabular}{|c|c|c|c|c|c|c|}
\hline \multirow[b]{2}{*}{$\begin{array}{l}\text { Type of } \\
\text { deposits }\end{array}$} & \multicolumn{6}{|l|}{ Timeline } \\
\hline & $\begin{array}{l}\text { July } 1971 \\
\text { to } \\
\text { May } 1974\end{array}$ & $\begin{array}{ll}\text { June } & 1974 \\
\text { to } & \text { June } \\
1986 & \end{array}$ & $\begin{array}{ll}\text { July } & 1986 \\
\text { to } & \text { May } \\
1996 & \end{array}$ & $\begin{array}{l}\text { June } 1996 \\
\text { to March } \\
2002\end{array}$ & $\begin{array}{l}\text { April } \\
2002 \text { to } \\
\text { March } \\
2005\end{array}$ & $\begin{array}{l}\text { From } \\
\text { April } \\
2005 \\
\text { onwards }\end{array}$ \\
\hline $\begin{array}{l}\text { Payment } \\
\text { and } \\
\text { settlement } \\
\text { deposits }\end{array}$ & & & & & & \\
\hline $\begin{array}{l}\text { Ordinary } \\
\text { deposits }\end{array}$ & & & & & & \\
\hline $\begin{array}{l}\text { Time } \\
\text { deposits }\end{array}$ & & & & & & \\
\hline $\begin{array}{l}\text { Maximum } \\
\text { deposit } \\
\text { insurance } \\
\text { coverage }\end{array}$ & $\begin{array}{l}1 \text { million } \\
\text { Yen } \\
\text { (principal) }\end{array}$ & $\begin{array}{l}3 \text { million } \\
\text { Yen } \\
\text { (principal) }\end{array}$ & $\begin{array}{l}10 \text { million } \\
\text { Yen } \\
\text { (principal) }\end{array}$ & $\begin{array}{l}\text { Full } \\
\text { coverage }\end{array}$ & $\begin{array}{l}10 \text { mill } \\
\text { (principal) } \\
\text { interest }\end{array}$ & $\begin{array}{l}\text { Yen } \\
\text { plus }\end{array}$ \\
\hline
\end{tabular}

Figure 7. Changes in Deposit Insurance Coverage in Japan (Overview of the Japanese Deposit Insurance Corporation of Japan (2009), with author's additions).

Note: As from April 2005 onwards, full coverage only applies to deposits that meet the following conditions: i) bearing no interest, ii) being redeemable on demand and iii) providing normally required payment and settlement services .

The experience of Japan illustrates that the extension of existing or introduction of new guarantees does not substitute for other measures that directly address the root causes of the lack of confidence; rather, it increases the need for the latter type of actions. Recent changes to deposit insurance parameters in many OECD countries are indeed just one type of a variety of very comprehensive measures undertaken to restore confidence and support financial intermediation. Some of these measures reflect a clear deviation from earlier case-by-case approaches and the general hope is that their more comprehensive nature may be successful in addressing the root causes of the current impairment of financial intermediation.

One risk, however, is that even the "new-generation" measures are not ambitious enough, not credible, or ill-focused. This situation may lead banks and other entities covered by the guarantees to believe that the extended guarantees will stay in place for longer than the government may have initially planned or announced. In some other cases, no specific deadlines have been set so far (e.g. Germany). Several governments have set specific deadlines for the extra deposit insurance to be withdrawn, such as end2009 (e.g. Austria and the United States), although such deadlines may be prolonged, 
and, in some cases, discussions have already started as to whether the measure initially invoked as temporary should not be prolonged or made permanent.

The outcome of the discussions regarding "exit" from extra deposit insurance arrangements will be influenced by the progress in resolving the banking crisis. In this context, an important aspect of these new measures is that they address the issue of the troubled assets on the balance sheets of banks. Resolving this issue is key to allow banks to resume lending and build up capital thorough their own business activity. There are however a variety of policy option to remove, guarantee, or otherwise insulate troubled assets from bank balance sheets. They differ regarding the extent of burdensharing between shareholder, debtholders and taxpayers, the allocation of ownership and control, and the allocation of responsibilities for managing assets (i.e. whether institutions are trusted to manage the assets on their own or whether the assets are separated and managed externally). Cross-country experience with the resolutions of weak financial institutions shows that there is no single best strategy and that asset disposition strategies need to be adapted to the changing circumstances of banking systems (Lumpkin, 2008). Different combinations of approaches have been adopted also in different OECD countries in the current crisis (see e.g. Figure 2), and in some cases, the initial approaches have been revised again. One factor that is complicating the choices of the latter is that the pool of troubled assets is not fixed, but that it is changing in composition and size as a result of the deteriorating macroeconomic outlook.

To the extent that the measures to insulate troubled assets are perceived as insufficient, banks may lose motivation to contribute to these efforts while deposits remain fully protected, thus creating additional moral hazard. As a consequence, the guarantees put in place would actually worsen the problem they are supposed to cure. Thus, the extension of existing or introduction of new guarantees does not substitute for other measures that directly address the root causes of the lack of confidence; rather, it increases the need for the latter type of actions.

An interesting question is to what extent government guarantees can effectively be completely withdrawn under all circumstances. To be sure, government guarantees can be withdrawn once times get better, that is once the crisis abates. However, once a government ventures down this road, there may be a general perception that a government guarantee will always be made available during a crisis situation. This situation is likely to create moral hazard.

\section{Conclusions}

Government provision of a safety net for banks and other financial institutions has been a key element of the policy response to financial crises. In the current crisis, the design of different financial safety net elements, including the deposit insurance function, has been redrawn in many jurisdictions. In the fall 2008, governments extended existing guarantees and introduced new ones in a series of radical policy actions. Many of these measures are consistent with the basic thrust of the arguments developed following the experience with Northern Rock, reflecting attempts to avoid having deposit insurance turn out to be the weak element of financial safety nets. Having said that, a few probably, and others certainly, exceed levels that would have been considered adequate before fall 2008. Alternatives to some of these measures may have been available and it 
is uncertain to what extent the actual choices made reflected the results of careful economic calculations as opposed to political considerations. ${ }^{4}$ The measures adopted are helpful in buying time; they are nonetheless not costless.

- First, like any guarantee, deposit insurance coverage gives rise to moral hazard. Arguably, moral hazard is most relevant in the case of (either implicit or explicit) provision of unlimited coverage.

Moral hazard is an important issue and should not be ignored, even if in the midst of a crisis the immediate task is to restore confidence and guarantees can be helpful in that respect (especially as customer deposits are a key source of bank funding). As important as the crisis itself is to the functioning of financial markets over the medium to long term is the immediate policy response to the crisis. Thus, even in the midst of a financial crisis, authorities should not loose sight of the fundamental policy goal of supporting efficiently operating financial markets. The manner in which policy makers address the current crisis will affect expectations about future policy choices and, perhaps, the likelihood and severity of future crises, through the impact it is likely to have on market discipline (which arguably has not worked properly before the current crisis).

Market discipline needs to be supported, and, to allow for a greater role for market discipline and limit moral hazard it is important to specify when the extra deposit insurance coverage will end. This timeline needs to be credible. Absent a credible "exit strategy", government guarantees once implemented can be difficult to withdraw, as the experience of Japan during its financial crisis in the 1990s illustrates. Clearly, it can be difficult in the midst of a crisis to specify specific timetables for phasing-out extended guarantees, as there will be considerable uncertainty as to the expected duration of the crisis. But providing guarantees for extensive periods, including for financial institutions that use extensive deposit insurance to maintain or gather funds to "gamblefor-redemption" in the attempt to avoid the inevitable bankruptcy raises the final costs of a crisis for the deposit insurer and the tax payer.

- Second, differences in retail deposit insurance guarantees across countries can also have implications for competition among banks operating in these markets. In that respect, cross-border co-ordination among authorities was not as close as one might have hoped, and as appears necessary to avoid the potential for unfair competitive advantages to arise. Also, within a given country, the coexistence of different levels of deposit insurance for host country banks and branches of foreign banks can also give rise to competition issues, as well as to consumer protection ones.

Convergence of the level of deposit insurance insurance ceilings across different jurisdictions towards a specific value would address both of these issues, although the

\footnotetext{
4 Ahking (2009) points out that the discussion of the expansion of deposit insurance guarantees, including the extension of unlimited coverage, could usefully be framed in terms of the question to what extent alternatives to unlimited guarantees were available and what are the economic costs and benefits associated with different policy options. Conceptual frameworks for such a discussion have been proposed by Kane and Klingebiel (2004) and Ergungor and Cherny (2009), although it is not clear to what extent such frameworks are used in practical crisis management and whether the political will exists to implement alternatives to expanded, and sometimes, unlimited guarantees.
} 
difficult decision would remain as to what specific value would suit all countries, if such a level exists at all. In practice, the response to the trade-offs involved in specifying coverage limits has differed between jurisdictions and reflected countryspecific circumstances. In any case, determining and announcing a timeframe for such convergence is particularly challenging in the midst of a crisis.

- Third, to make a guarantee credible it is important to specify how it will financially be provided. Recent developments indeed underscore the need for sound funding arrangements to ensure the effectiveness and credibility of the deposit insurance system (as well as other types of guarantees). In that context there may be a question regarding the capacity of (some) governments to provide for the implicit or explicit guarantee that they have announced.

Internationally co-ordinated efforts may be necessary to allow for successful rescue operations of banks operating across borders, and clear frameworks for such operations may need to be established, so as to reduce frictional costs that arise when international policy actions are decided during a crisis situation in a largely ad hoc fashion.

In addition to reducing such costs, international policy co-ordination is also required to avoid fostering competitive distortions. Ideally, measures to expand insurance of individual retail deposits beyond normal limits (and introduce additional guarantees of bank liabilities or assets) should be undertaken as part of cross-country co-ordinated efforts, with the timing of introduction and withdrawal of such temporary emergency measures be closely communicated and co-ordinated among policymakers.

More generally, the financial crisis has put the spotlight on the need for sound funding of safety nets. In this regard, one important insight is that the charging of riskbased premia on the institutions covered by the insurance is a means of limiting moral hazard. The current financial crisis might provide a useful opportunity to introduce and/or enhance the role played by such premia in the provision of deposit insurance going forward. In this context, it might be necessary to expand the set of financial institutions on which such charges are levied beyond the deposit-taking institutions that traditionally have been covered by deposit insurance and that have contributed to the funding of this element of the financial safety net. The set needs to include all financial institutions that are considered systemically important and that have benefitted from the expansion of existing, and the introduction of new, guarantees in fall 2008, including insurance and bank holding companies. The question of to what extent the other elements of the financial safety net apply to these types of institutions also needs to be addressed.

- Fourth, looking ahead, the policy focus will have to be on "exit strategies" and a question in this context is when and how to withdraw parts of the expanded and newly introduced guarantees, especially in those cases where clear and credible timeframes to that effect do not yet exist.

It is argued here that addressing the root causes of confidence problems becomes even more crucial when guarantees are expanded. Addressing the root causes effectively 
is a necessary condition for establishing credible timelines for withdrawal of what were conceived to be temporary guarantees.

- Fifth, another question is to what extent government guarantees can effectively be fully withdrawn under all circumstances. To be sure, government guarantees can be withdrawn once times get better, that is once the crisis abates. However, once a government has ventured down this road, there may be a general perception that a government guarantee will always be made available during a crisis situation.

Indeed, the policy actions taken today in response to the crisis are likely to be imprinted in the memories of market participants, including depositors and bank managers. There may be a general perception that, once a guarantee is extended in any given crisis, the specific type of government guarantee will always be made available during crisis situations. If true, it might be necessary to strengthen other elements of the financial safety net, including the prudential and supervisory framework, so as to limit moral hazard. For example, the current financial crisis provides a timely opportunity to revisit the issue of what deposit-taking banks should be allowed to do. In this context, it has been argued that banks should not be permitted to conduct both commercial-banktype and investment-bank-type activities with the same capital and that by appropriately delimiting the range of permitted activities of such institutions to relatively safe investments, the need for and potential role of deposit insurance altogether would be lessened, ${ }^{5}$ as deposits would tend to be safer anyway.

${ }^{5}$ See e.g. Todd (2009) and references therein. 


\section{References}

Ahking, F. (2009). Comments on Challenges Associated with the Expansion of Deposit Insurance During Fall 2008.

http://www.economics-ejournal.org/economics/discussionpapers/2009-16/view.

Borio, C. (2007). Change and Constancy in the Financial System: Implications for Financial Distress and Policy. BIS Working Paper 237. Bank for International Settlements, Basel.

Brunnermeier, M.K. (2009). Deciphering the Liquidity and Credit Crunch 2007-2008. Journal of Economic Perspectives, 23(1): 77-100.

Council of the European Union (2008). The Council approved general approaches on four 'financial services' dossiers. Brussels, 2 December 2008 16562/08 (Presse 352) (available at ue.eu.int/uedocs/NewsWord/en/misc/104473.doc).

Deposit Insurance Corporation of Japan (2009). Overview of the Japanese Deposit Insurance System. January 2009 (available at http://www.dic.go.jp/english/e_seido/e_seido.html) .

Demirgüç-Kunt, A., and E. Detragiache (2002). Does Deposit Insurance Increase Banking System Stability? An Empirical Investigation. Journal of Monetary Economics, 49(7): $1373-1406$.

Demirgüç-Kunt, A., and L. Servén (2009). Are All Sacred Cows Dead? Implications of the Financial Crisis for Macro and Financial Policies. World Bank Policy Research Working Paper 4807. World Bank, Washington, D.C.

Ergungor, O. E., and K. Cherny (2009). Economic Commentary. Effective Practices in Crisis Resolution and the Case of Sweden. Federal Reserve Bank of Cleveland. http://www.clevelandfed.org/research/commentary/2009/0209.cfm .

Financial Stability Forum Working Group on Deposit Insurance (2000). A Consultative Process and Background Paper, 12.

Financial Stability Forum (2001). Guidance for Developing Effective Deposit Insurance Systems. September.

Kane, E.J. and D. Klingebiel (2004). Alternatives to Blanket Guarantees for Containing a Systemic Crisis. Journal of Financial Stability 1: 31-63.

Keys, B.J, T. Mukherjee, A. Seru, and V. Vig (2008). Did Securitization Lead to Lax Screeing? Evidence from Subprime Loans. December, http://ssrn.com/abstract=1093137.

Laeven, L., and F. Valencia (2008a). Systemic Banking Crises: A New Database. IMF Working Paper 08-224. International Monetary Fund, Washington, D.

Laeven, L. and F. Valencia (2008b). The Use of Blanket Guarantees in Banking Crises. IMF Working Paper 08-250. International Monetary Fund, Washington, DC.

Lannoo, K. (2008). Concrete Steps towards More Integrated Financial Oversight-The EU's Policy Response to the Crisis. CEPS Task Force Report, December.

Lumpkin, S. (2002). Experiences with the Resolution of Weak Financial Institutions in the OECD Area. OECD Financial Market Trends, 82: 107-143.

Lumpkin, S. (2008). Resolutions of Weak Institutions: Lessons Learned from Previous Crises. OECD Financial Market Trends, 95: 113-154. 
Mendoza, E.G., and M.E. Terrones (2008). An Anatomy of Credit Booms: Evidence from Macro Aggregates and Firm Level Data. Paper presented at the Financial Cycles, Liquidty, and Securitization Conference hosted by the International Monetary Fund, 18 April 2008.

Nanto, D.K. (2008), "The U.S. Financial Crisis: Lessons From Japan”, CRS Report for Congress, Order Code RS22960, Updated September 29, 2008.

OECD (2007). Bank Profitability_Financial Statements of Banks. Paris: OECD.

Reinhart, C.M., and K.S. Rogoff (2009). The Aftermath of Financial Crises. NBER Working Paper 14656. National Bureau of Economic Research, Cambridge, MA.

Schich, S. (2008a). Financial Turbulence: Some Lessons Regarding Deposit Insurance, OECD Financial Market Trends, 94: 55-79.

Schich, S. (2008b). Financial Crisis: Deposit Insurance and Related Financial Safety Net Aspects, OECD Financial Market Trends, 95: 73-111.

Tamirisa, N.T. and D.O. Igan (2008). Are Weak Banks Leading Credit Booms? Evidence from Emerging Europe. IMF Working Paper 08-219. International Monetary Fund, Washington, DC.

Todd, W.F. (2009). Is this Risk Insurable? A Response to Sebastian Schich. Economics Discussion Papers, No 2009-21.

http://www.economics-ejournal.org/economics/discussionpapers/2009-21. 


\section{conomics}

The Open-Access, Open-Assessment E-Journal

\section{Please note:}

You are most sincerely encouraged to participate in the open assessment of this article. You can do so by either rating the article on a scale from 1 (bad) to 5 (excellent) or by posting your comments.

Please go to:

www.economics-ejournal.org/economics/journalarticles/2009-20

The Editor 